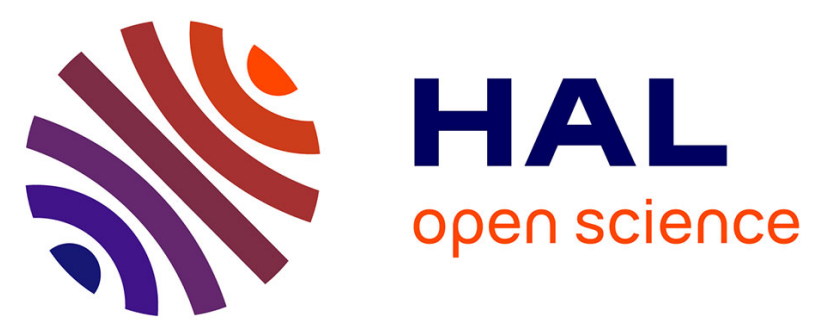

\title{
Stable monomeric intermediate with exposed Cys-119 is formed during heat denaturation of $\beta$-lactoglobulin
} Thomas Croguennec, Said Bouhallab, Daniel Mollé, Brendan T. O'kennedy, Raj Mehra

\section{- To cite this version:}

Thomas Croguennec, Said Bouhallab, Daniel Mollé, Brendan T. O'kennedy, Raj Mehra. Stable monomeric intermediate with exposed Cys-119 is formed during heat denaturation of $\beta$-lactoglobulin. Biochemical and Biophysical Research Communications, 2003, 301 (2), pp.465-471. 10.1016/S0006291X(02)02997-2 . hal-01569504

\section{HAL Id: hal-01569504 https://hal.science/hal-01569504}

Submitted on 26 Jul 2017

HAL is a multi-disciplinary open access archive for the deposit and dissemination of scientific research documents, whether they are published or not. The documents may come from teaching and research institutions in France or abroad, or from public or private research centers.
L'archive ouverte pluridisciplinaire HAL, est destinée au dépôt et à la diffusion de documents scientifiques de niveau recherche, publiés ou non, émanant des établissements d'enseignement et de recherche français ou étrangers, des laboratoires publics ou privés.

\section{다(1)(2)}

Distributed under a Creative Commons Attribution - ShareAlikel 4.0 International 


\title{
Stable monomeric intermediate with exposed Cys-119 is formed during heat denaturation of $\beta$-lactoglobulin
}

\author{
Thomas Croguennec, ${ }^{\mathrm{a}, \mathrm{b}, *}$ Saïd Bouhallab, ${ }^{\mathrm{a}}$ Daniel Mollé, ${ }^{\mathrm{a}}$ \\ Brendan T. O'Kennedy, ${ }^{\mathrm{b}}$ and Raj Mehra ${ }^{\mathrm{b}}$ \\ ${ }^{a}$ ENSA-INRA-CS 84215-65, rue de St Brieuc, Rennes cedex 35 042, France \\ b Dairy Products Research Center, Teagasc, Moorepark, Fermoy, Co. Cork, Ireland
}

Received 10 October 2002

\begin{abstract}
The role of the free sulfhydryl group of $\beta$-lactoglobulin in the formation of a stable non-native monomer during heat-treatment of $\beta$-lactoglobulin solutions was investigated. Two concomitant events occurred at the earlier stage of heating: unfolding of native globular monomer and intramolecular sulfhydryl/disulfide exchange reaction. Thus, two denatured monomeric species were formed: a non-native monomer with exposed Cys-121 (Mcys121) which became reversible after cooling, and a stable non-native monomer with exposed Cys-119 (Mcys119) which exhibited both a larger hydrodynamic conformation than native monomer and low solubility at $\mathrm{pH}$ 4.7. The results also show that the formation of these monomeric species throughout heat-induced denaturation of native $\beta-\lg$ monomers is faster than their subsequent aggregation. A mechanism describing the behavior of $\beta$-lg denaturation/aggregation during heat-treatment under selected conditions $\left(5.8 \mathrm{mg} / \mathrm{ml}\right.$, low ionic strength, $\left.\mathrm{pH} 6.6,85^{\circ} \mathrm{C}\right)$ is presented.
\end{abstract}

(C) 2003 Elsevier Science (USA). All rights reserved.

Keywords: $\beta$-Lactoglobulin A; Heat-treatment; Denaturation; $N$-Ethylmaleimide; Sulfhydryl group; Stable non-native monomer

$\beta$-Lactoglobulin $(\beta-\lg )$ is a globular protein with a molar mass of $18.3 \mathrm{Kg} / \mathrm{mol}$ present in bovine milk. $\beta$ - $\mathrm{Lg}$ is mainly responsible for the gelling properties of whey protein, and as such, a number of studies have investigated the denaturation/aggregation of $\beta-\lg$ under a wide range of $\mathrm{pH}$, ionic strength, and protein concentration conditions [1-7]. Under physiological conditions, $\beta$-lg exists as a dimer consisting of anti-parallel $\beta$-sheets formed by nine strands labeled A-I and one $\alpha$ helix. Each monomer has two disulfide bonds and one free sulfhydryl group, which is buried within the protein structure on the $\beta$-strand $\mathrm{H}$. Upon heating at neutral $\mathrm{pH}$, the native dimers dissociate into native monomers, which reversibly form a reactive monomer with a partially disrupted helix, leading to the exposure of the free sulfhydryl [8] and hydrophobic amino acids [9]. A pro-

\footnotetext{
${ }^{*}$ Corresponding author. Fax: +33-2-23-48-55-78.

E-mail address: Thomas.Croguennec@agrorennes.educagri.fr (T. Croguennec).
}

portion of these reactive species undergoes intermolecular sulfhydryl/disulfide interchange to give non-native dimers and larger species via further thiol-catalyzed disulfide bond interchange and the participation of noncovalent interactions depending on the salt concentration $[1,6,10]$ and the temperature of heat-treatment [11]. In addition to dimers, trimers, etc., unexpected stable non-native monomers were formed during the heattreatment of $\beta-\lg$ solutions. Stable non-native monomers behave like native proteins on SDS-PAGE but not on alkaline-PAGE $[12,13]$ and are eluted separately from the native monomers on gel permeation chromatography [13]. These are probably formed from native monomer proteins but the exact change leading to the stable non-native monomer is unclear $[8,12,13]$. It is also unclear whether the formation of such a stable nonnative monomer is essential for the heat-induced aggregation of $\beta-\lg$ [13].

In the present study, we investigated the heat-induced denaturation of $\beta-\lg$ and elucidated the structure and some specific properties of the stable non-native 
monomer formed during the early stages of $\beta$-lg denaturation/aggregation.

\section{Materials and methods}

Isolation of $\beta$-lg $A$ by anion-exchange chromatography and characterization by $S D S-P A G E$. The $\beta-\lg$ (variant A) was isolated according to a procedure adapted from [14].

The $\beta$-lg A obtained from the anion-exchange chromatography was checked for purity using SDS-polyacrylamide gel electrophoresis (PAGE) (under denaturing and reducing conditions). Electrophoresis was performed using a Mini Protean II system (Bio-Rad Laboratories, Alpha Technologies, Dublin, Ireland). SDS-slab polyacrylamide gel electrophoresis was conducted according to Laemmli [15] using a $15 \%$ acrylamide separating gel and a $4 \%$ acrylamide stacking gel, both containing $0.1 \%$ SDS. $\beta$ - Lg A was dispersed in SDS sample buffer containing mercaptoethanol and then heated at $95^{\circ} \mathrm{C}$ for $4 \mathrm{~min}$. Electrophoresis was carried out at constant current $(155 \mathrm{~V})$ for $50 \mathrm{~min}$ in a Tris-glycine buffer, $\mathrm{pH} 8.3$, containing $0.1 \%$ SDS. The gel was stained for proteins using Coomassie brilliant blue R250 $(0.05 \%$ in isopropanol:acetic acid:water in the ratio 0.25:0.1:0.65).

Sample preparation. Solutions of $\beta-\lg$ A $(10 \mathrm{~g} / \mathrm{L})$ were prepared by dissolving the freeze-dried $\beta$-lg in deionized water. The protein solutions were stirred for at least $3 \mathrm{~h}$ and then filtered through a $0.22 \mu \mathrm{m}$ non-protein-adsorbing filter (Acrodisc syringe filter, Gelman Science, Dun Laoire, Ireland). The $\mathrm{pH}$ was adjusted to 6.6 using $0.1 \mathrm{M} \mathrm{HCl}$ or $\mathrm{NaOH}$. The concentration of $\beta$-lg was determined from the absorbance of the solution at $278 \mathrm{~nm}$, using the specific extinction coefficient of $0.96 \mathrm{~L} / \mathrm{g} / \mathrm{cm}$, and the final concentration was adjusted to $7.0 \mathrm{~g} / \mathrm{L}$ with distilled water. Two hundred and sixty $\mu \mathrm{l}$ water or freshly prepared $2 \mathrm{mM} \mathrm{N}$-ethylmaleimide (NEM) was added to $1.3 \mathrm{ml}$ $\beta$-lg solution.

Kinetics of heat-induced denaturation/aggregation of $\beta$-lg. A series of tightly capped tubes containing $200 \mu \mathrm{l} \beta$-lg solutions, with or without added NEM, were heated in a water bath at $85^{\circ} \mathrm{C}$. At various time periods, tubes were removed and immediately cooled to $4^{\circ} \mathrm{C}$. Samples were then analyzed for disappearance of native $\beta$-lg and formation of oligomers using HP-GPC.

Determination of native $\beta$-lg and its oligomers by high-performance gel permeation chromatography (HP-GPC). For the determination of native $\beta$-lg concentration, $100 \mu \mathrm{l}$ of heated sample of $\beta$-lg solution was treated with $10 \mu \mathrm{l}$ acetic acid/sodium acetate $(0.5 \mathrm{M}, \mathrm{pH} 4.7)$ to induce precipitation of denatured/aggregated proteins. The denatured/aggregated proteins were removed by centrifugation at 20,000 $\mathrm{g}$ for $30 \mathrm{~min}$ in an Eppendorf centrifuge 5417C (Unitech, Dublin, Ireland).

Fifty $\mu$ lof original untreated or supernatant from acid-precipitated sample was diluted with $2.45 \mathrm{ml}$ phosphate buffer $(20 \mathrm{mM}, \mathrm{pH}$ 7.2) containing $0.05 \%$ of sodium azide. After filtration through a $0.22 \mu \mathrm{m}$ membrane filter (Acrodisc syringe filter, Gelman Science, Dun Laoire, Ireland), $10 \mu \mathrm{g}$ of the diluted sample was analyzed by high-performance gel permeation chromatography (HP-GPC). Samples were applied to a TSK G3000 SWXL $(300 \times 7.8 \mathrm{~mm}$ i.d. $)$ column (Labquip, Lucan, Ireland) connected to a HPLC system, consisting of a Waters 2690 Separation Module, a Waters 2487 Dual $\lambda$ Absorbance Detector, and a Millenium ${ }^{32}$ chromatography application software to acquire, process, and report chromatographic information. HPLC-grade acetonitrile (Sigma, Dublin, Ireland). The column was eluted with a phosphate buffer $(20 \mathrm{mM}, \mathrm{pH} 7.2)$ containing $0.05 \%$ of sodium azide at a flow rate of $0.8 \mathrm{ml} / \mathrm{min}$. UV absorption was measured at $278 \mathrm{~nm}$. Molecular masses of the constituent peaks eluted from the column were estimated using $\alpha$-lactabumin (14.2 kDa), ovalbumin (43 kDa), and bovine serum albumin (66 kDa) standards.

Tryptic hydrolysis. Samples were adjusted to $\mathrm{pH} 8.5$ with $\mathrm{NH}_{4} \mathrm{OH}$. Enzymatic hydrolysis was performed with trypsin at an enzyme/sub- strate molar ratio of $1 / 100$ at $40^{\circ} \mathrm{C}$ for $3 \mathrm{~h}$. The reaction was stopped by lowering the temperature in an ice/water bath. Hydrolysates were kept frozen until analyzed.

Mass spectrometry. Spectrometry was performed using a API-III Plus triple quadrupole mass spectrometer (Perkin-Elmer Sciex Instruments, Thornhill, Canada), fitted with articulated pneumatically assisted nebulization probes and an atmospheric-pressure ionization source. An ion spray voltage between +4.0 and $5.0 \mathrm{kV}$ (positive ionization) was applied. The nebulizer pressure was $0.315 \mathrm{MPa}$ and a $1.1 \mathrm{~L} /$ min counter-current flow of nitrogen between the ESI source and the nozzle was used. The orifice potential was set to $90 \mathrm{~V}$. The instrument mass-to-charge ratio scale was calibrated with the ions of the ammonium adduct of polypropylene glycol. Data were collected on a Power Macintosh 8100/80 and processed using the MacSpec 3.3 Sciex software.

$\beta$-Lactoglobulin and $\beta$-lactoglobulin digest mass analysis. For $\beta$-lg and $\beta-\lg / \mathrm{NEM}$ mass analysis, $\beta$-lg solutions were delivered to the sprayer by a syringe infusion pump (through a fused silica capillary of $0.75 \mu \mathrm{m}$ i.d.) at $5 \mu \mathrm{l} / \mathrm{min}$.

For the tryptic digests, a LC/MS/MS analysis was performed using a Reverse-phase Symmetry C18 column $(2.1 \times 125 \mathrm{~mm}$; Waters, Milford, MA) for peptide separations. The column was equilibrated with solvent A $(0.106 \%(\mathrm{v} / \mathrm{v})$ trifluoroacetic acid in Milli-Q water) and eluted with a linear gradient of $3-60 \%$ solvent B $(0.1 \%(\mathrm{v} / \mathrm{v})$ trifluoroacetic acid in 4:1 (v/v) acetonitrile:Milli-Q water) over $60 \mathrm{~min}$. RPHPLC separations were achieved at $40^{\circ} \mathrm{C}$ at a flow rate of $250 \mu \mathrm{l} / \mathrm{min}$ with a split to the MS ionization source to set a flow rate of $30 \mu \mathrm{l} / \mathrm{min}$. Peptides were detected at 214 and $280 \mathrm{~nm}$ using a HP1100 (Agilent technology, Waldbronn, Germany) and by total ion current (TIC) using the mass spectrometer described above. Collision-induced dissociation experiments were performed on selected ions with argon at a collision target gas thickness within the range $(2-3) \times 10^{15}$ atoms $/ \mathrm{cm}^{2}$, using collision energies of $25-50 \mathrm{eV}$, in accordance with the net charge state of the ions.

\section{Results}

In order to focus on the stable non-native $\beta$-lg monomer formed during the heat-treatment of $\beta-\lg$ solutions, experimental conditions were chosen that favored $\beta$-lg denaturation and hindered subsequent intermolecular sulfhydryl/disulfide exchange reactions. Solutions of $\beta-\lg \mathrm{A}$ at $\mathrm{pH}$ 6.6, at low ionic strength, in the absence or presence of NEM $(0.35 \mathrm{mM}$ as thiolblocking agent, $\beta$-lg/NEM molar ratio $\sim 1$ ), were heated at $85^{\circ} \mathrm{C}$ for various times. The denaturation/ aggregation behavior of $\beta-\lg \mathrm{A}$ as a function of heating time was followed by HP-GPC and mass spectrometry.

\section{Characterization of unheated $\beta$-lactoglobulin A}

The $\beta$-lg A preparation used in this study was a highly purified protein as shown in Fig. 1. Single protein band corresponding to $\beta-\lg$ A was observed in SDSPAGE.

HP-GPC profile of native $\beta-\lg$ A from unheated sample indicated the presence of two peaks (Fig. 2). One peak $(\mathrm{N})$ containing $95 \%$ of the protein had molecular mass (MM) calculated to be $21.2 \mathrm{kDa}$ and was attributed to the mixture of monomer and dimer in equilibrium. 


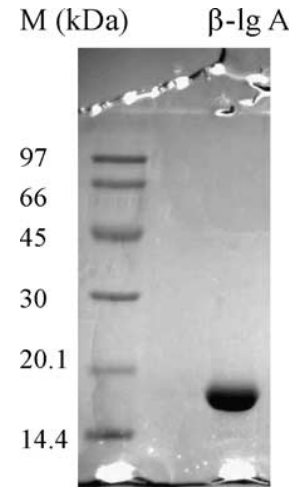

Fig. 1. $\beta$-Lactoglobulin A SDS-PAGE coupled with Coomassie brilliant blue staining method. M, low molecular weight markers.

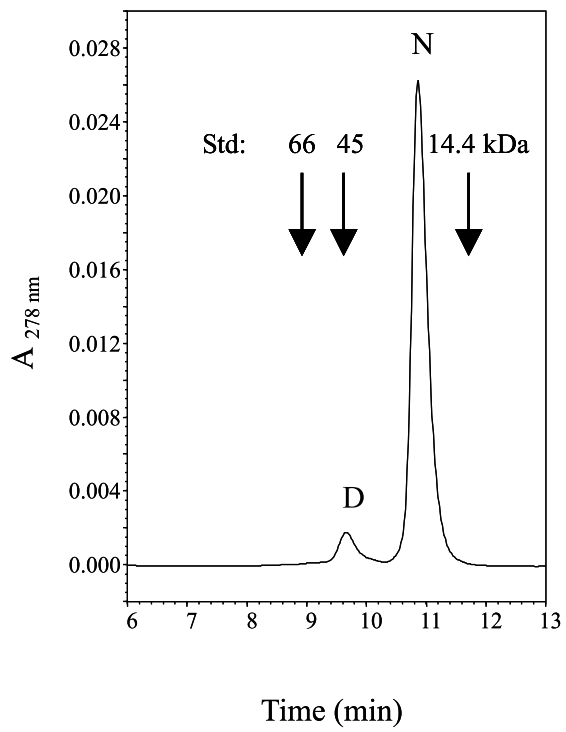

Fig. 2. High-performance gel permeation chromatography of unheated $\beta$-lactoglobulin A on a TSK G3000 SWXL $(300 \times 7.8 \mathrm{~mm}$ i.d. $)$ column. $\mathrm{N}$, native $\beta$-lactoglobulin; $\mathrm{D}, \beta$-lactoglobulin dimer; bovine serum albumin $(66 \mathrm{kDa})$, ovalbumin $(45 \mathrm{kDa})$, and $\alpha$-lactalbumin $(14.4 \mathrm{kDa})$ were used as standards $(\mathrm{Std})$.

Usually $\beta-\lg$ exists as a dimer at $\mathrm{pH}$ 7.2. However, the dimer-monomer equilibrium shifts to the monomer state under conditions of low $\beta$-lg concentration, low ionic strength, and high $\mathrm{pH}$ [16-19]. Extrapolation of the dimer-monomer equilibrium relationship to our conditions of analysis $(\mathrm{pH} 7.2,20 \mathrm{mM}$ phosphate, $0.116 \mathrm{~g} / \mathrm{L}$ protein) suggests that $10-20 \%$ of $\beta-\lg$ should exist in the dimeric form in accordance with the apparent MM determined in our study. The other peak had $5 \%$ of the protein (D) and was attributed to a fraction of non-native $\beta$-lg dimers, characterized by a non-native intermolecular disulfide bond, appearing inherently during the preparation of $\beta-\lg$ as only one $\beta-\lg$ band was observed by SDS-PAGE under reducing conditions.
Heat-induced denaturation/aggregation of $\beta$-lactoglobulin $A$

Heat-treatment of $\beta$-lg solution in the presence of NEM

The exposure of the free sulfhydryl group during the unfolding of the $\beta$-lg molecule on heating above the denaturation temperature has been implicated in the protein aggregation kinetics $[1,7,10]$. NEM has been extensively used as a thiol-blocking agent to study the kinetics of $\beta-\lg$ aggregation $[1,7,10,20]$. With the NEM/ $\beta$-lg molar ratio used in this study, no reaction between $\beta-\lg$ and NEM was observed by mass spectrometry analysis in the absence of heat-treatment. After 4 min of heating at $85^{\circ} \mathrm{C}$, all $\beta$-lg molecules had a mass addition of 125 which is characteristic of the fixation of one molecule of NEM per molecule of $\beta$-lg. No further modification was observed by mass spectrometry analysis on extended heating to $24 \mathrm{~min}$ (data not shown). Moreover, HP-GPC elution profiles show that aggregation of $\beta-\lg$ was prevented on heating $\beta-\lg$ solutions in the presence of NEM (Fig. 3). After heating, $98 \%$ of the $\beta$-lg molecules still eluted on HP-GPC with retention times between dimers and monomers, with no intermediate oligomers or larger aggregates formed. Hoffman and van Mill [10] observed the formation of larger protein aggregates in the presence of NEM compared to that in the absence of NEM, which they attributed to enhancement of non-specific bond formation. Xiong et al. [20] suggested that binding of NEM to the exposed thiol group increased molecular flexibility and enhanced interactions via non-specific bonding, thus resulting in

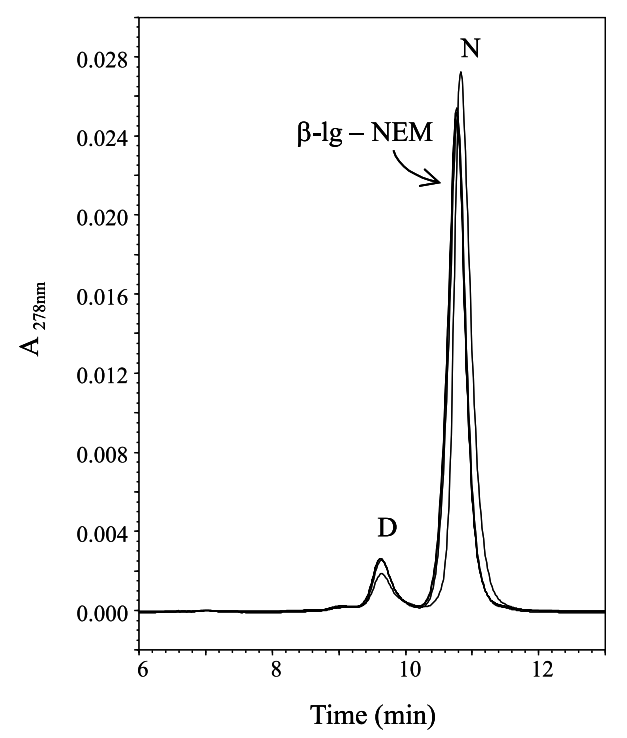

Fig. 3. High-performance gel permeation chromatography on a TSK G3000 SWXL $(300 \times 7.8 \mathrm{~mm}$ i.d. $)$ column of unheated $\beta$-lactoglobulin A solution containing $0.35 \mathrm{mM} N$-ethylmaleimide and $\beta$-lactoglobulin A solutions heated at $85^{\circ} \mathrm{C}$ in the presence of $0.35 \mathrm{mM} \mathrm{N}$-ethylmaleimide for $4.5 ; 11.5$ and $24 \mathrm{~min}$. $\mathrm{N}$, native $\beta$-lactoglobulin; $\mathrm{D}$, dimer; $\beta$ lg-NEM, NEM-modified $\beta$-lactoglobulin. 


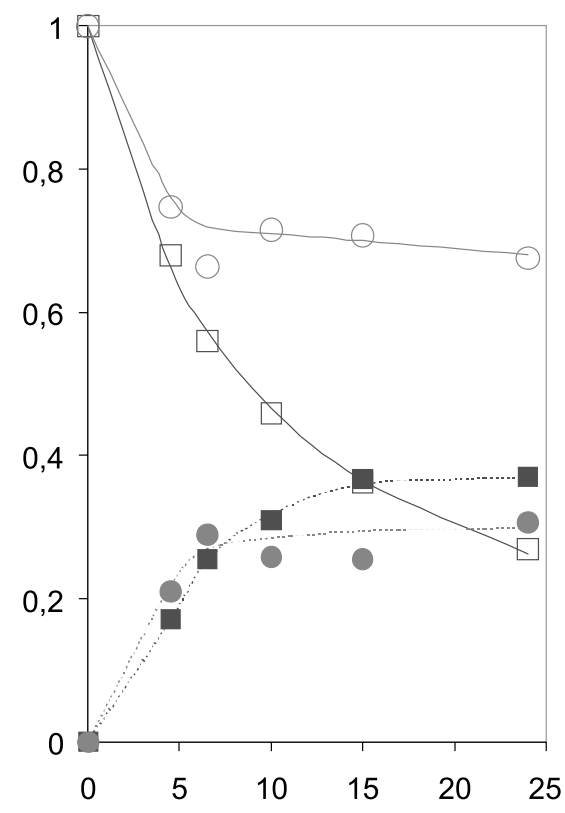

Fig. 4. Experimental concentration fraction of $\mathrm{pH} 4.7$-soluble $\beta$-lactoglobulin (open form) and $\mathrm{pH}$ 4.7-precipitated $\beta$-lactoglobulin monomer (full form) as a function of heating time at $85^{\circ} \mathrm{C}$. Square, in the absence of $N$-ethylmaleimide; circle, in the presence of $0.35 \mathrm{mM}$ $N$-ethylmaleimide.

large aggregate formation. However, in this study, no protein aggregation was observed on heating of $\beta-\mathrm{lg}$ solutions in the presence of NEM, suggesting that aggregation of $\beta$-lg in the absence of NEM is the direct result of intermolecular sulfhydryl/disulfide interchange. It was observed repeatedly that the retention time of the $\beta-\lg$ molecule decreased on heating in the presence of NEM (Fig. 3). All $\beta$-lg molecules after 4 min of heattreatment at $85^{\circ} \mathrm{C}$ and cooling exhibited a decrease in retention time compared to the unheated $\beta$-lg molecules. No further difference in the chromatographic profiles was observed on extended heating to $24 \mathrm{~min}$ at $85^{\circ} \mathrm{C}$.

In the presence of NEM, approximately $30 \%$ of heattreated $\beta$-lg molecules precipitated at $\mathrm{pH} 4.7$, whereas no precipitation was observed before heating (Fig. 4). No further precipitation of molecules was observed after $24 \mathrm{~min}$ of heating at $85^{\circ} \mathrm{C}$. These results suggested that heat-treatment of $\beta-\lg$ solutions in the presence of NEM generated at least two molecular species which eluted under the same chromatographic peak on HP-GPC.

Characterization of $\beta$-lg species formed during the heattreatment of $\beta$-lg solutions in the presence of NEM

To identify structural differences between the two heat-induced molecular species of $\beta$-lg, a trypsinolysis under non-reduced conditions was carried out on a $\beta-1 \mathrm{~g}$ solution heat-treated in the presence of NEM and on the supernatant of the same solution after precipitation at $\mathrm{pH}$ 4.7. The tryptic digests were analyzed by reverse phase HPLC coupled with ESI-MS (Fig. 5). Cross-

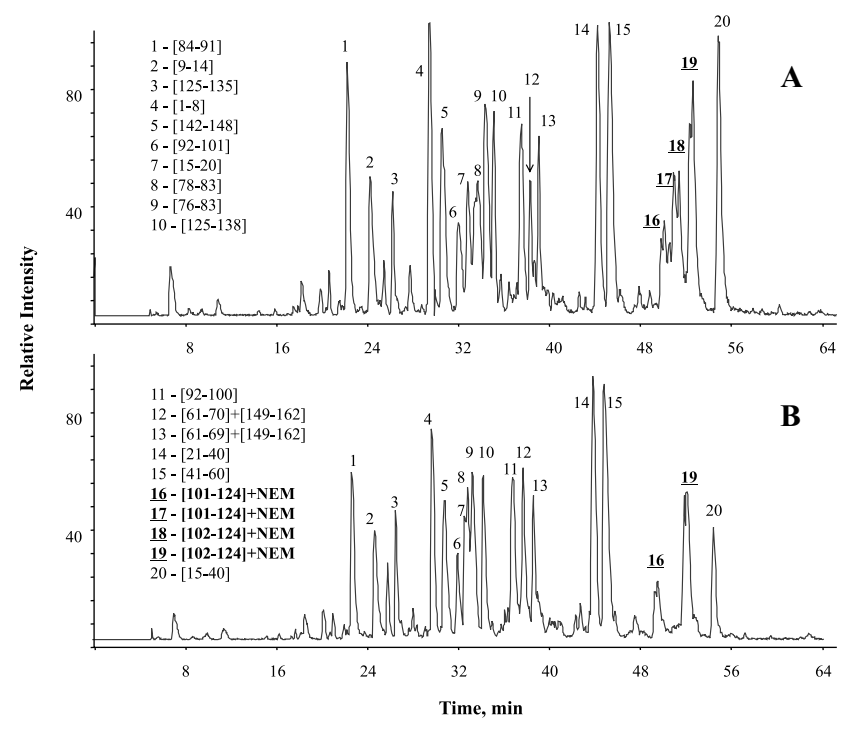

Fig. 5. Chromatographic profiles of the tryptic digest of $\beta$-lactoglobulin solutions heated at $85^{\circ} \mathrm{C}$ for $4 \mathrm{~min}$ in the presence of $\mathrm{N}$-ethylmaleimide before (A) and after (B) precipitation of the denatured protein at $\mathrm{pH}$ 4.7. Peptides were identified according their mass by ESI-MS.

checking both, the primary sequence of $\beta-\lg$ and the trypsin specificity, enabled us to identify the tryptic peptides according to their MM. In addition, those presenting a mass addition of 125 on the known MMs of the tryptic peptides due to the fixation of NEM were also identified. Twenty peptides were identified in the tryptic digest of the $\beta$-lg solution heat-treated in the presence of NEM (Fig. 5A). Eighteen of these 20 peptides were conserved in the supernatant (after precipitation at $\mathrm{pH} 4.7$ ) of tryptic digest of $\beta$-lg solution heat-treated in the presence of NEM (Fig. 5B). The native disulfide bond Cys-66/Cys-160 was conserved in all $\beta$-lg molecules heat-treated in the presence of NEM. The only modified peptides by a mass addition of 125 were the peptides 101-124 and 102-124. They are identified by the underlined numbers $16,17,18$, and 19 in Fig. 5A and 16 and 19 in Fig. 5B. Thus, NEMmodified peptides 17 and 18 were characteristic of $\beta-\mathrm{lg}$ molecules precipitating at $\mathrm{pH} 4.7$.

NEM-modified peptides identified in Figs. 5A and B were collected for collision-induced dissociation experiments in order to localize the NEM binding site. In addition to the presence of a sulfhydryl blocked by NEM, each peptide 101-124 or 102-124 was stabilized by one disulfide bond. The behavior of $\beta$-lg molecules at pH 4.7 depended on the sulfhydryl site that reacted with NEM and consequently the localization of the disulfide bond. In the $\beta$-lg molecules remaining soluble at $\mathrm{pH} 4.7$, the Cys-121 was blocked with NEM and the disulfide bond was Cys-106/Cys-119 whereas the Cys-119 was blocked with NEM and the disulfide bond was Cys-106/ Cys-121 in the molecules precipitating at $\mathrm{pH} 4.7$. 
Heat-treatment of $\beta$-lg solution in the absence of NEM

Following heat-treatment of $\beta$-lg solutions in the absence of NEM, the concentration of native $\beta$-lg decreased. Native $\beta-\lg (\mathrm{N})$ in heat-treated solution refers to $\beta$-lg molecules remaining soluble at $\mathrm{pH} 4.7$ and having the same retention time in HP-GPC as $\beta$-lg molecules from unheated solution. A decrease in the concentration of native $\beta$-lg on heating followed an increase in the concentration of intermediate oligomers [dimer, (D); trimer, (T); ...] (Fig. 6). A stable $\beta$-lg conformer (noted $\mathrm{nN}$ on the HP-GPC profiles) with a HPGPC retention time slightly lower than for the averaged dimer-monomer equilibrium mixture of $\beta$-lg (Fig. 6) and an apparent $\mathrm{MM}$ of $24.5 \mathrm{kDa}$ was also formed. It was not detected on SDS-PAGE (data not shown) and was easily precipitated by lowering the $\mathrm{pH}$ to 4.7 (Fig. 7). The stable $\beta$-lg conformer was not present in the unheated solution and therefore must be related to the heat-induced alterations to the native $\beta-\lg$ structural conformation. Its lower retention time on HP-GPC and its low solubility at $\mathrm{pH} 4.7$ highly suggested that the stable $\beta$-lg conformer had the same structural conformation as $\beta-\lg$ molecules that had reacted with NEM at position 119 . The proportion of the stable $\beta$-lg conformer precipitating at $\mathrm{pH} 4.7$ increased in the early stages of heat-treatment to reach a plateau, at approximately $40 \%$ of the total $\beta-\lg$ molecules (Fig. 4). In the presence of NEM, the HP-GPC retention time shift was therefore not the only fact of NEM binding to $\beta-1 g$ molecules but was related to a heat-induced alteration on the structural conformation of native $\beta-\lg$.

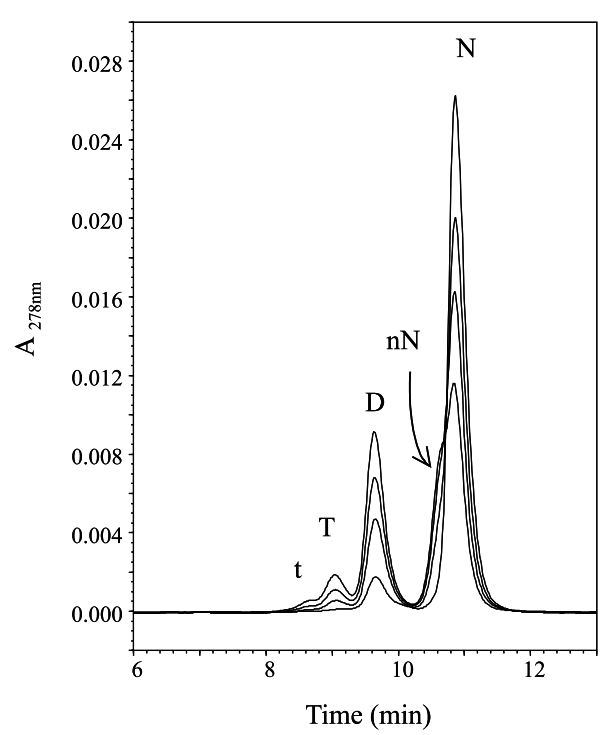

Fig. 6. High-performance gel permeation chromatography on a TSK G3000 SWXL $(300 \times 7.8 \mathrm{~mm}$ i.d. $)$ column of unheated $\beta$-lactoglobulin A solution and $\beta$-lactoglobulin A solutions heated at $85^{\circ} \mathrm{C}$ in the absence of $N$-ethylmaleimide for $4.5 ; 11.5$ and $24 \mathrm{~min}$ from top to bottom at $11 \mathrm{~min}$. $\mathrm{N}$, native $\beta$-lactoglobulin; $\mathrm{D}$, dimer; $\mathrm{T}$, trimer; $\mathrm{t}$, tetramer; and $\mathrm{nN}$, non-native $\beta$-lactoglobulin monomer.

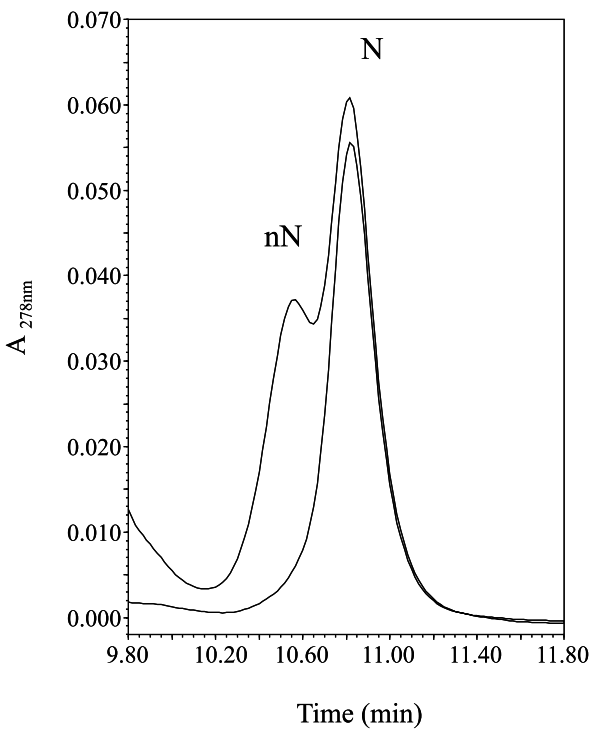

Fig. 7. High-performance gel permeation chromatography of $\beta$-lactoglobulin A focus on the non-native monomer chromatographic peaks. $\beta$-Lactoglobulin heated at $85^{\circ} \mathrm{C}$ for $24 \mathrm{~min}$ (two chromatographic peaks, $\mathrm{nN}$ and $\mathrm{N}$ ); $\beta$-lactoglobulin obtained after precipitation at $\mathrm{pH}$ 4.7 of the heat-induced denatured/aggregated protein at $85^{\circ} \mathrm{C}$ for 24 min (one chromatographic peak, $\mathrm{N}$ ); $\mathrm{N}$, native $\beta$-lactoglobulin; and $\mathrm{nN}$, non-native $\beta$-lactoglobulin monomer.

\section{Discussion}

This study showed that heat-treatment of $\beta$-lg solutions led to the formation of a stable $\beta$-lg monomer with low solubility at $\mathrm{pH} 4.7$ and shorter retention time on HP-GPC with respect to the expected behavior of the native $\beta-\lg$ monomer. It was characterized by Cys-106/ Cys-121 and Cys-66/Cys-160 intramolecular disulfide bonds and the free sulfhydryl Cys-119 (Mcys119). It is highly likely that this $\beta$-lg monomer is the stable nonnative monomer observed by other workers $[8,12,13]$. The chemical reactivity of Mcys119 free sulfhydryl can be explained either by the presence of free sulfhydryl Cys-119 buried in the native protein or by its formation throughout sulfhydryl/disulfide rearrangement occurring during heat-treatment. The first explanation is based on the work of McKenzie et al. [21] who suggested that free sulfhydryl Cys-121 and Cys-119 are equally likely to participate in the disulfide bond with Cys-106 in the native protein. However, crystallographic [22], ${ }^{13} \mathrm{C}$ NMR [23], and Cys-121 or Cys-119 site directed mutagenesis [24] studies ruled out the occurrence of free sulfhydryl Cys-119 in the native $\beta$-lg. It is now largely accepted that the one mole of sulfhydryl per mole of native $\beta-\lg$ monomer is entirely due to the free sulfhydryl at the position Cys-121 rather than a mixture of free sulfhydryl at positions Cys-119 and Cys-121. Consequently, the formation of Mcys119 implies an intramolecular sulfhydryl/disulfide exchange reaction between the free sulfhydryl Cys-121 and the Cys-106/Cys-119 


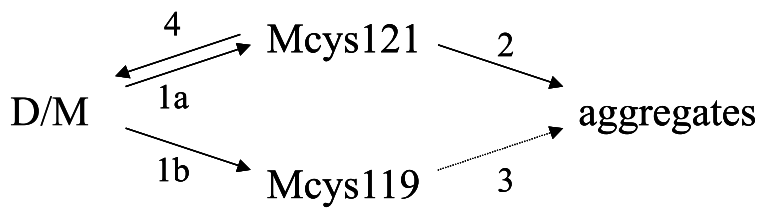

Fig. 8. Scheme of the first events taking place during the heat-induced denaturation/aggregation of $\beta$-lactoglobulin $\mathrm{D} / \mathrm{M}$, dimer-monomer equilibrium mixture at $20^{\circ} \mathrm{C}$; Mcys 121 , non-native $\beta$-lg monomer with Cys-121 exposed to the solvent reversibly formed during heattreatment of $\beta$-lg solutions; Mcys119, non-native $\beta$-lg monomer characterized with non-native intramolecular disulfide bonds; and the Cys-119 exposed to the solvent formed irreversibly during heat-treatment of $\beta$-lg solutions; aggregates (dimer, trimer, ...).

disulfide bond connecting the $\beta$-strand $\mathrm{H}$ and the $\beta$ strand $\mathrm{G}$ of the calyx of the native $\beta$-lg [25]. The close proximity of the sulfur atoms of Cys-121 free sulfhydryl and Cys-106/Cys-119 disulfide bond $(10.5 \AA)$ is compatible with intramolecular sulfhydryl/disulfide exchange reactions [26]. The molecular rearrangement involves a significant conformational change in the native $\beta$-lg structure which could explain the low solubility of the newly formed stable non-native $\beta-1 \mathrm{~g}$ monomer (Mcys119) at $\mathrm{pH} 4.7$.

These observations are combined in the reaction scheme presented in Fig. 8, in which the following events take place in order. Heat-treatment of $\beta$-lg solutions at neutral $\mathrm{pH}$ rapidly shifts the dimer-monomer equilibrium mixture (native $\beta-\lg$ ) to non-native $\beta$-lg monomers with an exposed sulfhydryl group. Some are exposed at position Cys-121 (Mcys121) (step 1a) and others at the position Cys-119 (Mcys119) due to the concomitant intramolecular sulfhydryl/disulfide interchange (step 1b). Both of them are able to polymerize into aggregates but with different polymerization rates (steps 2 and 3 ). Steps $1 \mathrm{a}$ and $1 \mathrm{~b}$ are faster than steps 2 and 3, leading to the rapid accumulation of unfolded monomers Mcys121 and Mcys119, because chemical blocking of exposed free sulfhydryl Cys-121 and Cys-119 prevents polymer formation. After cooling, Mcys121 reversibly forms the native $\beta-\lg$ (step 4), as the kinetics of disappearance of native $\beta-\lg$ is slow compared to Mcys 121 reactivity with NEM. Comparatively, Mcys 119 molecules are trapped in a stable non-native conformation that does not return to the native state. Hence, Mcys119 has a non-native behavior either by HP-GPC or by reducing the $\mathrm{pH}$ to 4.7. The disappearance of native $\beta-\lg$ and the build up of Mcys119 may indicate that Mcys121 has a higher reactivity than Mcys119 as suggested by Schokker et al. [13].

Since Mcys119 elution time on HP-GPC was the same as that of NEM-modified $\beta$-lg, this implies that the observed shift toward shorter retention time is due to the formation of $\beta$-lg molecules with a more open structure rather than the addition of NEM reagent. This could be a consequence of Cys-121 or Cys-119 sulfhydryl exposition to the solvent associated with a change in protein hydration as hydration is closely related to protein conformation [27]. However, intramolecular sulfhydryl/disulfide interchange could participate in an extended exposition of inner hydrophobic amino acids as only molecules with Cys-119 exposed sulfhydryl have a low solubility at $\mathrm{pH} 4.7$. In order to verify this hypothesis, the conformational change induced by the intramolecular sulfhydryl/disulfide interchange will be investigated in future studies. Formation of stable nonnative monomers with Cys-119 exposed sulfhydryl also occurred during alkaline denaturation of $\beta$-lg and by action of urea [23]. The same intramolecular sulfhydryl/ disulfide interchange was suggested to explain Cys-119 reactivity. It may be possible that $\beta-\lg$ denaturation and the intramolecular sulfhydryl/disulfide rearrangement are concomitant, whatever the denaturing conditions used. However, the extended conformational changes of Mcys119 and consequently its physicochemical properties could be dependent on the denaturing conditions used. In our experimental conditions, the proportion of Mcys 119 was limited to $30-40 \%$ of total $\beta-\lg$ molecules but it may be dependent on the physicochemical conditions of $\beta-\lg$ solution those governing the relative speeds of both, $\beta$-lg denaturation and intramolecular sulfhydryl/disulfide interchange. The influence of varying the physicochemical conditions of $\beta$-lg solution on the formation of Mcys119 will be investigated in future studies.

\section{Acknowledgments}

This work was supported by a grant from the Conseil Regional de Bretagne, France. We thank Prof. G. Brulé for helpful discussions.

\section{References}

[1] W.H. Sawyer, Heat denaturation of bovine $\beta$-lactoglobulin and relevance of disulfide aggregation, J. Dairy Sci. 51 (3) (1968) 323-329.

[2] W.G. Griffin, M.C.A. Griffin, S.R. Martin, J. Price, Molecular basis of thermal aggregation of bovine $\beta$-lactoglobulin A, J. Chem. Soc. Faraday Trans. 89 (18) (1993) 3395-3406.

[3] S.P.F.M. Roefs, K.G. de Kruif, A model for the denaturation and aggregation of $\beta$-lactoglobulin, Eur. J. Biochem. 226 (1994) 883889.

[4] P. Aymard, J.C. Gimel, T. Nicolai, D. Durand, Experimental evidence for a two-step process in the aggregation of $\beta$-lactoglobulin at pH 7, J. Chim. Phys. 93 (1996) 987-997.

[5] X.L. Qi, C. Holt, D. McNulty, D.T. Clarke, S. Brownlow, G.R. Jones, Effect of temperature on the secondary structure of $\beta$ lactoglobulin at $\mathrm{pH}$ 6.7, as determined by $\mathrm{CD}$ and IR spectroscopy: a test of the molten globule hypothesis, Biochem. J. 324 (1997) 341-346.

[6] M. Verheul, S.P.F.M. Roefs, K.G. de Kruif, Kinetics of heatinduced aggregation of $\beta$-lactoglobulin, J. Agric. Food Chem. 46 (1998) 896-903.

[7] N. Kitabatake, R. Wada, Y. Fujita, Reversible conformational change in $\beta$-lactoglobulin A modified with $N$-ethylmaleimide and 
resistance to molecular aggregation on heating, J. Agric. Food Chem. 49 (2001) 4011-4018.

[8] S. Iametti, B. de Gregori, G. Vecchio, F. Bonomi, Modifications occur at different structural levels during the heat denaturation of $\beta$-lactoglobulin, Eur. J. Biochem. 237 (1996) 106-112.

[9] G. Palazolo, F. Rodriguez, B. Farruggia, G. Pico, N. Delorenzi, Heat treatment of $\beta$-lactoglobulin: structural studied by partitioning and fluorescence, J. Agric. Food Chem. 48 (2000) 38173822 .

[10] M.A.M. Hoffmann, P.J.J.M. van Mil, Heat-induced aggregation of $\beta$-lactoglobulin: role of the free thiol group and disulfide bonds, J. Agric. Food Chem. 45 (1997) 2942-2948.

[11] M.A.M. Hoffmann, P.J.J.M. vanMil, Heat-induced aggregation of $\beta$-lactoglobulin as a function of $\mathrm{pH}, \mathrm{J}$. Agric. Food Chem. 47 (1999) 1898-1905.

[12] G.A. Manderson, M.J. Hardman, L.K. Creamer, Effect of heat treatment on the conformation and aggregation of $\beta$-lactoglobulin A, B and C, J. Agric. Food Chem. 46 (1998) 5052-5061.

[13] E.P. Schokker, H. Singh, D.N. Pinder, G.E. Norris, L.K. Creamer, Characterization of intermediates formed during heatinduced aggregation of $\beta$-lactoglobulin $\mathrm{AB}$ at neutral $\mathrm{pH}$, Int. Dairy J. 9 (1999) 791-800.

[14] K.R. Kristiansen, J. Otte, R. Ipsen, K.B. Qvist, Large scale preparation of $\beta$-lactoglobulin A and $\mathrm{B}$ by ultrafiltration and ionexchange chromatography, Int. Dairy J. 8 (1998) 113-118.

[15] U.K. Laemmli, Cleavage of structural proteins during the assembly of the head of bacteriophage T4, Nature 227 (259) (1970) 680-685.

[16] M.J. Kelly, F.J. Reithel, A thermodynamic analysis of the monomer-dimer association of $\beta$-lactoglobulin A at the isoelectric point, Biochemistry 10 (13) (1971) 2639-2644.

[17] M. Verheul, J.S. Pedersen, S.P.F.M. Roefs, K.G. de Kruif, Association behavior of native $\beta$-lactoglobulin, Biopolymers 49 (1999) 11-20.
[18] D. Galani, R.K. Owusu Apenten, $\beta$-Lactoglobulin denaturation by dissociation-coupled unfolding, Food Res. Int. 32 (1999) 93-100.

[19] R.K. Owusu Apenten, D. Galani, Thermodynamic parameters for $\beta$-lactoglobulin dissociation over a broad temperature range and pH 2.6 and 7.0, Thermochim. Acta 359 (2000) 181-188.

[20] Y.L. Xiong, K.A. Dawson, L. Wan, Thermal aggregation of $\beta$ lactoglobulin: effect of $\mathrm{pH}$ ionic environment and thiol reagent, J. Dairy Sci. 76 (1) (1993) 70-77.

[21] H.A. McKenzie, G.B. Ralston, D.C. Shaw, Location of sulfhydryl and disulfide groups in bovine $\beta$-lactoglobulins and effects of urea, Biochemistry 11 (24) (1972) 4539-4547.

[22] S. Brownlow, J.H. Morais Cabral, R. Cooper, D.R. Flower, S.J. Yewdall, I. Polikarpov, A.C.T. North, L. Sawyer, Bovine $\beta$ lactoglobulin at 1.8 resolution-still an enigmatic lipocalin, Structure 5 (1997) 481-495.

[23] P. Phelan, J.P. Malthouse, ${ }^{13} \mathrm{C}$ NMR of the cyanylated $\beta$ lactoglobulins: evidence that Cys-121 provides the thiol group of $\beta$-lactoglobulins A and B, Biochem. J. 302 (1994) 511-516.

[24] L. Sawyer, J.H. Morais Cabral, C.A. Batt, Protein engineering studies of $\beta$-lactoglobulin, in: A.T. Andrews, J. Varley (Eds.), Biochemistry of Milk Products, The royal Society of Chemistry, Cambridge, UK, 1994, pp. 114-126.

[25] M.Z. Papiz, L. Sawyer, E.E. Eliopoulos, A.C.T. North, J.B.C. Findlay, R. Sivaprasadarao, T.A. Jones, M.E. Newcomer, P.J. Kraulis, The structure of $\beta$-lactoglobulin and its similarity to plasma retinol-binding protein, Nature 324 (1986) 383-385.

[26] J. Yang, J.R. Powers, S. Clark, A.K. Dunker, B.G. Swanson, Hydrophobic probe binding of $\beta$-lactoglobulin in the native and molten globule state induced by high pressure as affected by $\mathrm{pH}$, $\mathrm{KIO}_{3}$, and $N$-ethylmaleimide, J. Agric. Food Chem. 50 (2002) $4207-5214$.

[27] N. Taulier, T.V. Chalikian, Characterization of $\mathrm{pH}$-induced transitions of $\beta$-lactoglobulin: ultrasonic densitometric and spectrometric studies, J. Mol. Biol. 314 (4) (2001) 873-889. 